\title{
Antecedents of Return on Venture Capital Investment - Evidence From Chinese Growth Enterprise Market
}

\author{
Crystal Xiaobei Chen \\ Harbin Institute of Technology Shenzhen China \\ Peipei Zhao \\ Shenzhen GDR Carbon Exchange \\ Qiumei Jane Xu \\ Northeastern Illinois University
}

This study examined how enterprise growth factors affect the return on venture capital investment for enterprises listed on Chinese Growth Enterprise Market (GEM). Using a sample of 235 venture capital backed enterprises listed on Chinese GEM over three years, we collected data from each company's prospectus and listing documents. We also collected data from Chinese QINGKE Research Center Database. We found that (1) three growth factors (profitability, operational capability and innovation capability) were positively associated with venture capital return. (2) Both the composite growth indicator and the optimized composite growth indicator are positively related to venture capital return. The theoretical and practical implications are discussed.

Keywords: small and medium sized enterprises (SMEs), enterprise growth, venture capital, return on investment

\section{INTRODUCTION}

Growing interest had been developed and extensive entrepreneurship research has been explored to understand the dynamics of venture capital, particularly, the rate of return to these investments. Venture capital investment literature has traditionally focused on portfolio returns for venture capital funds. The deal-specific investment has been largely ignored (Mason, 2002). With the limited research on deal-specific venture capital investment, most of them work on the characteristics of investment such as the way in which business angels harvested their investment and the length of the holding period (Mason, 2002). Information is limited in entrepreneurial enterprise factors that lead to different levels of investment return in venture capital.

The limited number of research on deal-specific investment made by institutional venture capital investment firms relates to the sensitivity of the information. However, the overall performance of a fund is crucially dependent on the presence of a small number of very successful investments. These investments are the ones that are generally harvested by means of an Initial Public Offering (IPO) (Mason, 2002). On 
the other hand, how can small and medium sized enterprises (SMEs) attract financial resources is always a big challenge for them. Typically venture capitalists are expected to focus on innovation, knowledge transfer and the like (Manigart, 2002). Manigart (2002) found that the distribution of returns to informal venture capital investment is highly skewed and required venture capital return vary systematically by stage, average size of investment, and by country.

This study continues the work on answering what leads to higher return on venture capital for specific projects, and in particular it attempts to examine the relationship between entrepreneurial enterprise growth factors and return on venture capital in small business and entrepreneurship. Challenges faced by SMEs in financing are even more pronounced in emerging economies such as China due to a weak institutional environment (Huang, Boateng, \&Newman, 2016). In order to improve access to external finance for growth SMEs, China has established a Growth Enterprises Market (GEM) Board in 2009 as part of its efforts to accelerate the development of Small and Medium-sized Enterprises (SMEs). Chinese GEB is a separate listing venue for smaller, fast growing and entrepreneurial companies and follows the practices of the NASDAQ market for SMEs in the USA. It aims to provide a platform where SMEs can obtain financing through public offering. The GEM has lower listing requirements for initial public offerings (IPOs) by Chinese start-up companies than those listed companies on the mainboard. As of the end of 2013, about 350 listed firms were trading on the Chinese GEM Board. Among the firms listed on the GEM, 77 are from the telecommunication industry and 229 are from the high-tech or technology-intensive manufacturing industry. Almost all firms on the GEM Board are under the control of private investors or firms.

Thus, we seek to answer the question that what factors may influence deal-specific venture capital investment? We propose that enterprise growth can be considered as a valid tool to predict the return on venture capital investment. Enterprise growth will be conceptualized and different dimensions of enterprise growth will be discussed. A unique dataset in Chinese GEM market will be analyzed to test the hypotheses. This article contributes to the existing literature in the following ways. First, we are among the few studies that examine the dynamics of deal-specific venture capital investment. Second, we will introduce the concept of enterprise growth and explore how different enterprise growth factors affect the return on venture capital in a transitional and emerging economy. Third, we extend the western literature by using a unique dataset in a transitional economy to test our hypotheses.

The rest of this article is organized as follows. In the next section it reviews the extant literature relevant to venture capital investment return and enterprise growth and proposes hypotheses related to venture capital return. Then the research methodology is presented and data analysis techniques are discussed. Next, the findings are summarized and discussed. The paper concludes with a discussion of theoretical implications for future research and managerial implications for entrepreneur policy makers.

\section{LITERATURE REVIEW}

Extensive research has examined how Venture capital (VC) backed firms can perform better than nonVC backed firms (Grilli, 2014, Gompers and Lerner, 2001). However, whether this investment ultimately leads to the high return of investment is not clear. One of the major criteria for determining venture investment is that VC investors are better at screening entrepreneurial firms that have high growth potential. Following the path, we would like to examine whether it is valid for venture capitalists to use potential growth as one of the major evaluation criteria. In this paper, we would like to examine for the financial viability and innovation capability characteristics of the portfolio companies that relate to the higher return of investment using a unique dataset from Chinese GEM.

Researchers found mixed results in terms of the return of venture capital. Kaplan and Scholar (2005) reported that performance of private equity fund is equivalent to the return on S\&P500 although substantial heterogeneity across funds exists. Phalippou and Gottschalg (2006) found that the performance of private equity funds is below that of the S\&P 500. Other researchers have worked on the various factors that influence the return of venture capital. Externally, the factors include economic circles and industrial policy. Neto, Filho and Quelhas (2014) found that venture capital investment in the United States varies by the different economic circles. Vissing (2000) found that return on private venture capital was largely impacted 
by different economic policies. Management, quality of the team and level of entrepreneurial skills is also found to be related to the performance of venture funds (Neto, 2014). Using a unique dataset of 163 venture capital-backed portfolio companies (PFCs), Gerasymenko (2015) found that the performance of young ventures is positively related to the scope of venture capital firm involvement. Manigart (2002) found that required returns on venture capital is positively associated with venture capital companies providing more intensity of involvement and having shorter expected holding period of the investment. Mason (2004) argued that venture capital firms invest for capital gain and they share in the success of the businesses that they invest in. Their investment is also fully exposed in the event that the business fails. Accordingly, venture capital firms might place great emphasis on the capability of the management team, the product and service and the market. They focus on factors such as entrepreneur or management team, strategy, operations, product or service, market, financial considerations, investor fit and so on. They further found that venture capital firms give greater emphasis to market issues and financial issues. Two further criteria: the entrepreneur and strategy are of secondary importance. The nature of venture capital also related to the return on venture capital investment. Erik and Lehmann (2006) found that syndicated venture capital investment showed significant higher return. Smolarski and Kut (2011) found that the type of equity-based venture capital financing has various effects on the performance of small and medium sized enterprises. Using a new European Union-sponsored firm-level longitudinal dataset, Grilli, Murtinu and ilano (2014) found that government-managed capital and independent venture capital funds have significant different impact on the performance of European entrepreneurial firms. The positive and statistically significant impact of syndicated investments by both types of investors on firm sales growth, but only when led by IVC investors. Chahine and Filatotchev (2008) suggested that IPOs with affiliated VCs in general, and particularly those affiliated with more prestigious underwriters, have a higher long-term abnormal return than both non-affiliated and non-VC-backed IPOs. Fitza and Sharon (2009) found that venture capital ownership and year effects accounted for significant variance in performance. Richardson (2003) found that the more money was raised in the venture fund's vintage year, the worse is the fund's subsequent performance. Finally, Fleming (2004) found that return on venture capital is related to different institutional types.

Among all research on venture capital return, one of the factors that may lead to higher return on venture capital investment is the enterprise growth for the entrepreneurial firms. Mason (2009) set out some basic measurement indicators on high-growth and they asked for more understanding about the drivers of the growth. Croce (2013) measured firm growth by employing the growth in labor productivity and capital productivity in European venture capital (VC) backed firms in high-tech industries. Based on a longitudinal dataset of 200 U.S.-based venture capital firms over a twelve-year period, De Clercq and Dimov (2003) found that investment specialization in terms of industry and development stage has a positive effect on firm growth. They also found that whereas the degree of syndication at the initial investment round negatively affected investment performance, the total involvement by the investment syndicate over time has a positive impact on firm growth. Delmar, Davidsson and Gartnr (2003) explored heterogeneity in how firms have achieved high growth. Using the population of all firms in Sweden. They used nineteen different measures of firm growth and identified seven different types of firm growth patterns. Delmar, Mckelvie, and Wenneberg (2013) found strong support for the notion that profitability enhances both survival and growth, and growth helps profitability but has a negative effect on survival. Thus this paper will focus on the enterprise growth factors such as profitability, operational capability, solvency, cash flow and innovation.

\section{Hypotheses}

Researchers and practitioners have paid great attention to the relationship between the performance of funded firms and the return of the venture capital (Rosenbusch, Brinckmann, \& Muller, 2012). Consistent with the resource-based view (Barney 1991), sound growth of small and medium sized enterprises usually start with achieving sufficient level of profitability (Davidsson, 2009). Profitability is the foundation of sustaining growth for businesses. Numerous studies have empirically explored the correlation between growth and profitability (Capon, Farley, \& Hoenig, 1990; Coad, 2006, Davidsson, 2009)

Journal of Applied Business and Economics Vol. 24(1) 2022 
Venture capital firms give greater attention to financial returns. They are return-driven. The sole objective of venture capital is to generate financial returns to investors. Profitability is one of the most important metrics that reflected a firms' financial return and financial health. A business that is highly profitable has the ability to reward its investors with a large return on their investment. No business can survive for a significant amount of time without making a profit. Profitability reflects the operation situation of the company. Higher level of profitability attracts venture capital and is a good criterion that venture capitalists uses for evaluating investment projects. Business with higher profitability can quickly find the funding to support their financing and attract good management team. Venture capitals are frequently portrayed as investors that create value by providing financial resources as well as value-added functions such as managerial resources and access to the VC's social capital and assurance to the founders and other resource providers including employees, customer, suppliers and other investor, which may lead to higher profitability for the entrepreneurial businesses. Cao (2008) found that private equity investment in enterprises with high profitability enterprises receive higher investment return. Zuo (2013) considered profitability as one indicator of enterprise growth. Wang (2013) examined Chinese small and medium-sized board listed companies and found that venture capital investing in enterprise with high profitability tend to have higher return on investment. $\mathrm{Yu}$ (2011) proposed that the profitability of enterprise is positively related to the return of the venture capital investment. Enterprise profitability indicates higher corporate profits. Thus, we propose that

\section{Hypothesis 1: Growth enterprise profitability is positively related to return on venture capital.}

Researchers also believed that the monitoring of the funded firms might help firms in using their resources more efficiently (Amit, et al., 1998; Barry et al., 1990, Gompers, 1995, Sahlman, 1990). Operational capability is defined as a firm's ability to use resources effectively (Miller \& Roth 19994). Firms gain an operating advantage by efficiently leveraging their resources to create operating income. Operational efficiency creates value that cannot be easily substituted. Operational capabilities can provide sustained competitive advantage (Hayes \& Upton, 1998). A study of 870 U.S. software companies over the period of 1995-2007 found that companies with high level of innovation-related competitive actions but low operational capability were 466 per cent more likely to fail than the average. For a lot of entrepreneurial firms, operational skills were the key to avoiding corporate failure (Li, Shang, \& Slaughter, 2010). The study showed the importance of operational capabilities and the need for management focusing in this area in order to sustain its competitive advantages. Zuo (2013) analyzed the impact of operational capability on business growth and proposed that the value of the enterprise can be increased by improving its operational capability. Thus, we propose that

\section{Hypothesis 2: Growth enterprise operational capability is positively related to return on venture capital.}

Solvency is another indicator of an enterprise's state of financial health. It refers to an enterprise capacity to meet its long-term financial commitments. One of the indicators of the growth potential of a company is whether it is able to repay the debt in time. If the ratio is too high, it could mean that the company will become insolvent before turning profit and paying back the debt. Companies with good ratio of solvency are in a healthy financial situation. It indicated that enterprise assets are sufficient to cover its liabilities. Good ratio of solvency assures the growth of companies and leads to higher value of firms. Zuo (2013) proposed that solvency was one of the indicators of business growth for evaluating the value of investment institutions; Yu (2011) found that enterprise solvency was positively associated with annual return on investment. Zhang (2013) stated that debt-paying ability is an important measure of enterprises growth. Thus, we propose that

Hypothesis 3: Growth enterprise solvency is positively related to return on venture capital. 
Liquidity is another term that reflects an enterprise's state of financial health. It refers to an enterprise's ability to pay short-term obligations. Cash flow is critical for the health of a business. Strong cash flow provides the comfort and capabilities a business needed to invest in growth. Many companies have shown profits but stumbled later because of insufficient cash flow. Getting to a position of excess cash flow helps the company operate in a strategic, proactive way. Cash flow also gives the company great flexibility in responding to uncertain environment. Confidence in cash flow makes it easier to make critical decisions benefit for the company in the long run.

The venture capital is concerned with getting a satisfactory return on the investment. They are concerned with the company's cash-flow rights allocated to venture capital. When the uncertainty and the risk of the investment increases, the venture capital will value the venture lower and demand a higher fraction of the cash flow rights as a compensation for the investment (Boocock, et al, 1997). One of the management performance indicators is whether the company has a manageable cash burn rates and is expected to be cash-flow break even within 12 months in the past, and their cash low is positive to date. The cash flows are extremely important for early-stage ventures. Thus, we propose that

\section{Hypothesis 4: Growth enterprise cash flow is positively related to return on venture capital.}

Established corporations seeking growth and financial return today face an increasing need to innovate. Venture capital typically provides funding for costly technological innovation to generate returns for investors. Companies backed by venture capital focus on building up of absorptive capacity, engaging in in-house research and development while at the same time acquiring external knowledge. Absorptive capacity was the capacity to identify, assimilate and exploit new knowledge that has been generated outside of the firm, thereby absorbing it (Cohen \& Levinthal, 1989, 1990). The dynamic capability nature of absorptive capacity allows companies to learn from both in-house and external knowledge (Zahra \& George, 2002). Thus, innovation is a source of competitive advantage (Cassiman \& Betugelers, 2002) that contributes to the company's financial performance, which leads to higher return of venture capital. Da Rin and Penans (2015) found that firms engaged in "make and buy" obtain a higher percentage of their sales from innovative products. Bottazzi and Da Rin (2002) found that venture capital backed companies tend to have superior performance in producing commercially successful new technology. Venture capital typically has a finite life span and they would like to have an innovation strategy that can lead to the generation of commercially mature products and services within a short period. This strategy is to build up absorptive capacity through both internal and external research and development. Delmar (2003) found that venture capital considered innovation as an important indicator of investment in growth enterprise. Yu (2011) found that $R \& D$ investment is positively related to corporate growth. Venture capitalists typically favor company with high innovation capability. Thus, we propose that

\section{Hypothesis 5: Growth enterprise innovation capability is positively related to return on venture capital.}

\section{Hypothesis 6: Enterprise growth is positively related to return on venture capital.}

\section{Methods}

Sample

Our sample consists of all 333 companies listed on the Chinese Growth Enterprise Market from October 2009 (the date that Chinese GEB market opened) up to June 2012, of which 235 were venture capital backed enterprises. The venture capital backed enterprises are defined as one of the top ten stockholders in the company's prospectus and also documented in the QINGKE Research Center Database. As the venture capital backed enterprises may have different venture capital backed, 379 samples were created. We collected data from each company's prospectus and listing documents. We also collected data from QINGKE Research Center Database. 


\section{Variables}

The dependent variable is the average annual rate of return on venture capital. The independent variables are profitability, solvency, operational capability, cash flow and innovation. The entrepreneurial venture characteristics such as size, age and ownership concentration are controlled, as well as the characteristics of venture capital companies such as location and size. Table 1 summarizes the definition and description of all the variables.

\section{Analysis}

The composite indicator of enterprise growth was measured by conducting the factor analysis. Factor analysis of the basic model as shown in

$Y=\alpha_{0}+\alpha_{1} X_{1}+\alpha_{2} X_{2}+\alpha_{3} X_{3}+\alpha_{4} X_{4}+\cdots \ldots \alpha_{k} X_{k}+\delta$

Next, we ran three-step multiple regression models to examine the relationship between enterprise growth and the return on venture capital investment.

(1) The regression analysis between five common factors $F_{1} \sim F_{5}$ and return on venture capital;

(2) The regression analysis between comprehensive evaluation index $\mathrm{F}$ and return on venture capital;

(3) The regression analysis between comprehensive optimally evaluation index F' and return on venture capital. Multiple regression model as shown in (2)-(4):

$I R=\alpha_{0}+\alpha_{1} F_{1}+\alpha_{2} F_{2}+\alpha_{3} F_{3}+\alpha_{4} F_{4}+\alpha_{5} F_{5}+\alpha_{6} C V_{1}+\alpha_{7} C V_{2}+\alpha_{8} C V_{3}+\alpha_{9} C V_{4}+\alpha_{10} C V_{5}+\delta$

$I R=\alpha_{0}+\alpha_{1} F+\alpha_{2} C V_{1}+\alpha_{3} C V_{2}+\alpha_{4} C V_{3}+\alpha_{5} C V_{4}+\alpha_{6} C V_{5}$

$I R=\alpha_{0}+\alpha_{1} F^{\prime}+\alpha_{2} C V_{1}+\alpha_{3} C V_{2}+\alpha_{4} C V_{3}+\alpha_{5} C V_{4}+\alpha_{6} C V_{5}+\delta$

Note: IR denotes return on venture capital, $\alpha_{i}$ denotes regression coefficient of enterprises growth factors, Fi denotes the common factors, $\mathrm{F}$ denotes the comprehensive evaluation index of enterprises growth, $\mathrm{F}^{\prime}$ denotes the comprehensive optimally evaluation index of enterprises growth, CVi denotes the control variable index in venture capital $(i=1 \sim 5)$. 


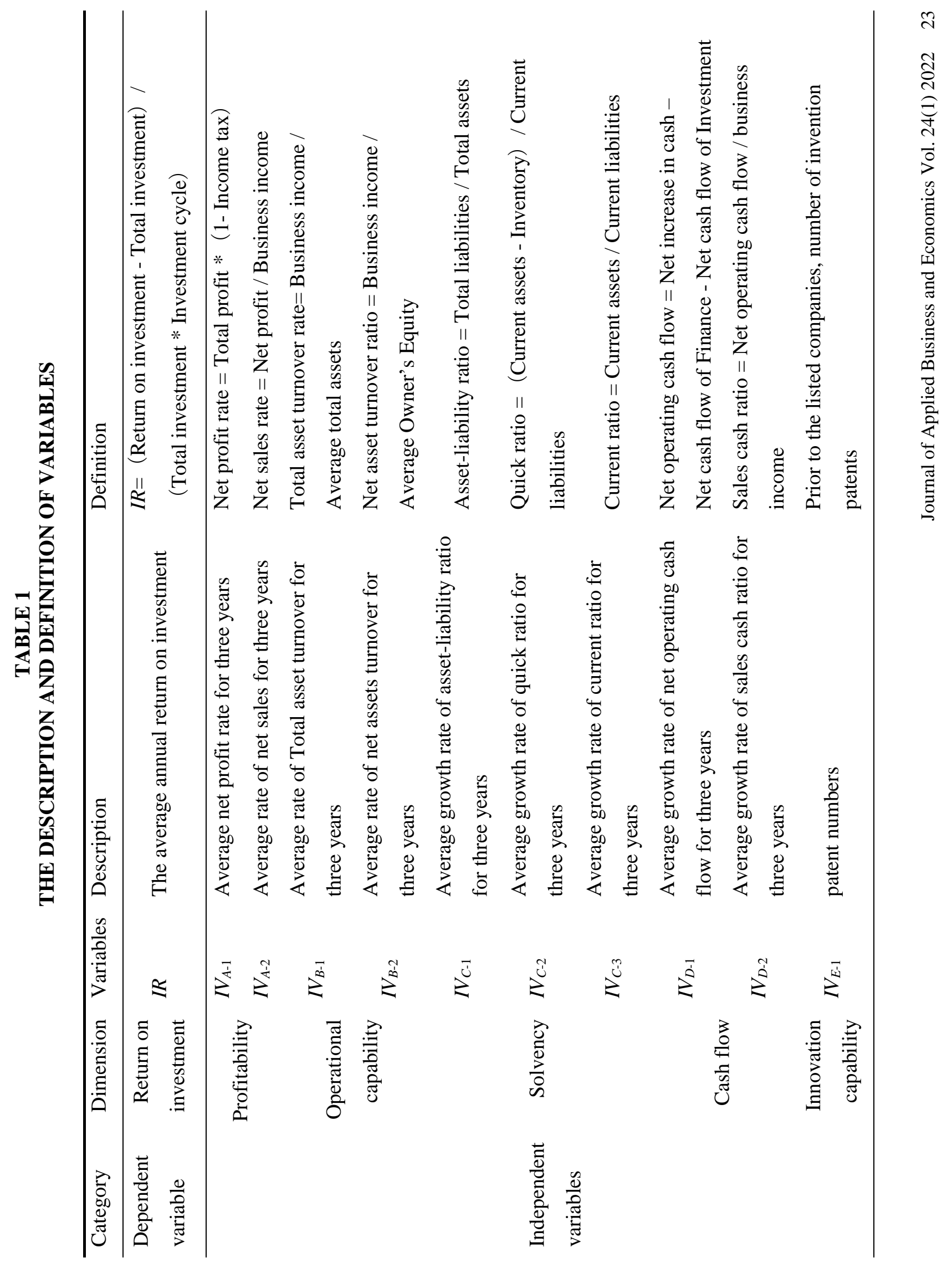




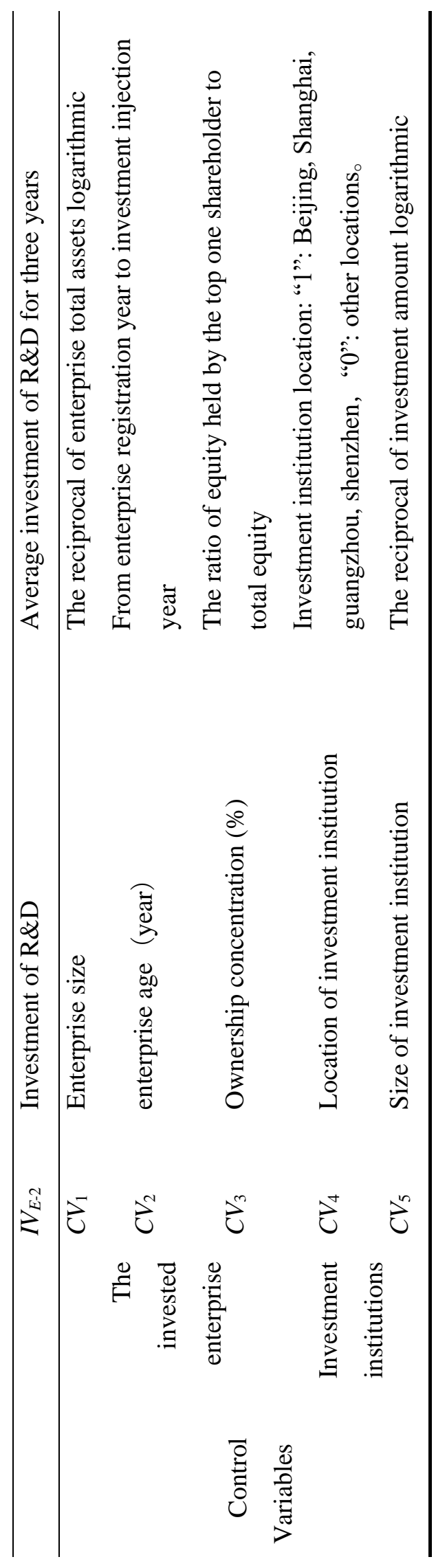




\section{RESULTS}

\section{Factor Analysis of Enterprise Growth Variables}

The KMO and Bartlett test of enterprises growth showed that $\mathrm{KMO}$ value was $0.544(\mathrm{P} \leq 0.01)$. Thus factor analysis was conducted accordingly and the results were shown in Table 2. Five factors with value of greater than 1.0 emerged and accounted for $73.868 \%$ of the total variance. Factor one was defined as the solvency factor, Factor two was defined as the cash flow factor, Factor three was defined as the profitability factor, Factor four was defined as the operational capability factor, and Factor Five was defined as the innovation factor corresponding to different variables. The composite enterprise growth index as created by the following formula:

\section{$F=0.2790 F_{1}+0.2334 F_{2}+0.2200 F_{3}+0.1398 F_{4}+0.1279 F_{5}$ \\ TABLE 2 \\ FACTOR ANALYSIS OF ENTERPRISE GROWTH}

\begin{tabular}{|c|c|c|c|c|c|c|c|c|}
\hline & \multicolumn{3}{|c|}{ Initial Eigenvalues } & \multicolumn{3}{|c|}{ Extraction Sums of Squared } & \multicolumn{2}{|c|}{ Rotating Sums of Squared } \\
\hline \multirow[t]{2}{*}{ Index } & & Variance & Accumulation & & Variance & Accumulation & & Accumulation \\
\hline & Sum & $\%$ & $\%$ & Sum & $\%$ & $\%$ & Sum Variance $\%$ & $\%$ \\
\hline 1 & 2.472 & 22.475 & 22.475 & 2.472 & 22.475 & 22.475 & 2.26720 .606 & 20.606 \\
\hline 2 & 1.913 & 17.394 & 39.869 & 1.913 & 17.394 & 39.869 & 1.89717 .243 & 37.849 \\
\hline 3 & 1.660 & 15.090 & 54.959 & 1.660 & 15.090 & 54.959 & 1.78716 .249 & 54.097 \\
\hline 4 & 1.131 & 10.283 & 65.241 & 1.131 & 10.283 & 65.241 & 1.13610 .326 & 64.423 \\
\hline 5 & 1.049 & 8.626 & 73.868 & 1.049 & 8.626 & 73.868 & 1.0399 .445 & 73.868 \\
\hline 6 & 0.891 & 8.104 & 81.971 & & & & & \\
\hline 7 & 0.822 & 7.473 & 89.444 & & & & & \\
\hline 8 & 0.661 & 6.005 & 95.449 & & & & & \\
\hline 9 & 0.354 & 3.219 & 98.669 & & & & & \\
\hline 10 & 0.121 & 1.097 & 99.765 & & & & & \\
\hline 11 & 0.026 & 0.235 & 100.000 & & & & & \\
\hline
\end{tabular}

Note: Extract is the analysis of main component.

Statistical Analysis Between the Enterprise Growth Factors and Return on Venture Capital

As shown in Table 3, profitability was significantly related to return on venture capital $(b=0.05, p<$ .05 ) and Hypothesis 1 was supported. Operational capability was positively related to venture capital return. Hypothesis 2 was supported $(b=0.06, p<.05)$. The relationship between solvency and return on venture capital was not significant, thus, Hypothesis 3 was not supported. The relationship between cash flow and return on venture capital was not significant, thus, Hypothesis 4 was not supported. Innovation capability was positively related to return on venture capital $(b=0.12, p<.05)$.

In order to further validate the results in this paper, we performed the grey relational model analysis between enterprises growth factors and return on venture capital and found no significant difference among the three relationships. We also ran the regression analysis between the composite enterprise growth index and return on venture capital. As shown in Table 4, the composite enterprise growth index was significantly related to return on venture capital $(b=0.11, p<.01)$. 
TABLE 3

REGRESSION ANALYSIS BETWEEN THE ENTERPRISE GROWTH FACTORS AND RETURN ON VENTURE CAPITAL

\begin{tabular}{|c|c|c|c|c|c|}
\hline \multirow[t]{2}{*}{ Model } & \multicolumn{2}{|c|}{$\begin{array}{c}\text { Unstandardized } \\
\text { Coefficients }\end{array}$} & \multirow[t]{2}{*}{$\begin{array}{c}\text { Standardized } \\
\text { Coefficients }\end{array}$} & \multirow[b]{2}{*}{$\mathrm{t}$} & \multirow[b]{2}{*}{ Sig. } \\
\hline & $\mathrm{B}$ & Standard error & & & \\
\hline Constant & 15.961 & 5.201 & - & 3.069 & 0.002 \\
\hline$F_{1}$ & 0.273 & 0.301 & 0.045 & 0.907 & 0.365 \\
\hline$F_{2}$ & -0.152 & 0.302 & -0.025 & -0.505 & 0.614 \\
\hline$F_{3}$ & 0.358 & 0.304 & 0.059 & 1.176 & 0.041 \\
\hline$F_{4}$ & 0.701 & 0.302 & 0.116 & 2.321 & 0.021 \\
\hline$F_{5}$ & 0.656 & 0.302 & 0.109 & 2.175 & 0.030 \\
\hline$C V_{1}$ & 12.218 & 18.200 & 0.035 & 0.671 & 0.042 \\
\hline$C V_{2}$ & 0.227 & 0.087 & 0.137 & 2.605 & 0.010 \\
\hline$C V_{3}$ & 0.005 & 0.025 & 0.011 & 0.221 & 0.025 \\
\hline$C V_{4}$ & 1.253 & 0.668 & 0.095 & 1.877 & 0.021 \\
\hline$C V_{5}$ & 394.423 & 77.642 & 0.258 & 5.080 & 0.000 \\
\hline \multirow{2}{*}{\multicolumn{2}{|c|}{$\mathrm{R}^{2}$}} & \multicolumn{4}{|c|}{ Change statistics } \\
\hline & & \multicolumn{2}{|c|}{ Change of $\mathrm{R}^{2}$} & $\mathrm{df} 1 \quad \mathrm{df} 2$ & Change of Sig. F \\
\hline 0.439 & & \multicolumn{2}{|c|}{0.111} & $10 \quad 368$ & 0.000 \\
\hline
\end{tabular}

Further, as the results shown in Table 2 that solvency factor and cash flow factor were not significantly related to the return on venture capital, these two factors were dropped and we created the optimized enterprise growth index:

$$
F^{\prime}=0.4511 F_{3}+0.2867 F_{4}+0.2622 F_{5}
$$

Another round of regression analysis was conducted between optimized enterprise growth index and return on venture capital. The results were shown in table 5, enterprise growth coefficient of optimization of comprehensive evaluation index is $0.149, \mathrm{p}<0.01$. It showed that the relationship between optimized comprehensive evaluation and the return on venture capital is more significant, compared with comprehensive evaluation. Thus, Hypothesis 6 was supported (Table 5).

\section{DISCUSSION}

The article shed light on the question in terms of factors that can influence the return of venture capital on specific projects. As one of the few studies that examine the dynamics of deal-specific venture capital investment, this study extended the western literature by using a unique dataset in a transitional economy to test our hypotheses.

Using a sample of 235 venture capital backed enterprises listed on the Chinese Growth Enterprise Market from October 2009 up to June 2012, we focused on deal-specific investments and found that entrepreneurial enterprises growth is positively associated with venture capital return. Particularly three indicators of enterprise growth, profitability, solvency and innovation capability are positively related to the return of venture capital. Both the composite growth indicator and the optimized composite growth 
indicator are positively related to venture capital return, although the latter fits the model better. No significant relationship was found between venture capital return and solvency and cash flow. In addition, the analysis of the grey relational model between enterprises growth and return on venture capital suggests that the influence degree of the risk investment return are ranked "operation ability> innovation > profitability". As highlighted by Gompers and Lerner (2001), one of the pending research questions is the causality of the firm performance and the presence of $\mathrm{VC}$. In fact, the higher performance or firm growth found in VC-backed firms is related to the presence of VCs, but it might also be explained by the attractiveness of firms with greater business opportunities. In other words, VC-backed firms might be better than non-VC-backed ones before the first round of $\mathrm{VC}$ financing. As our data is collected for the first round of $\mathrm{VC}$ financing (IPO), the higher performance of VC-backed firms can be better (at least partially) explained by the 'screening' ability of VCs.

TABLE 4

REGRESSION ANALYSIS BETWEEN COMPOSITE ENTERPRISE GROWTH INDEX F AND RETURN ON VENTURE CAPITAL

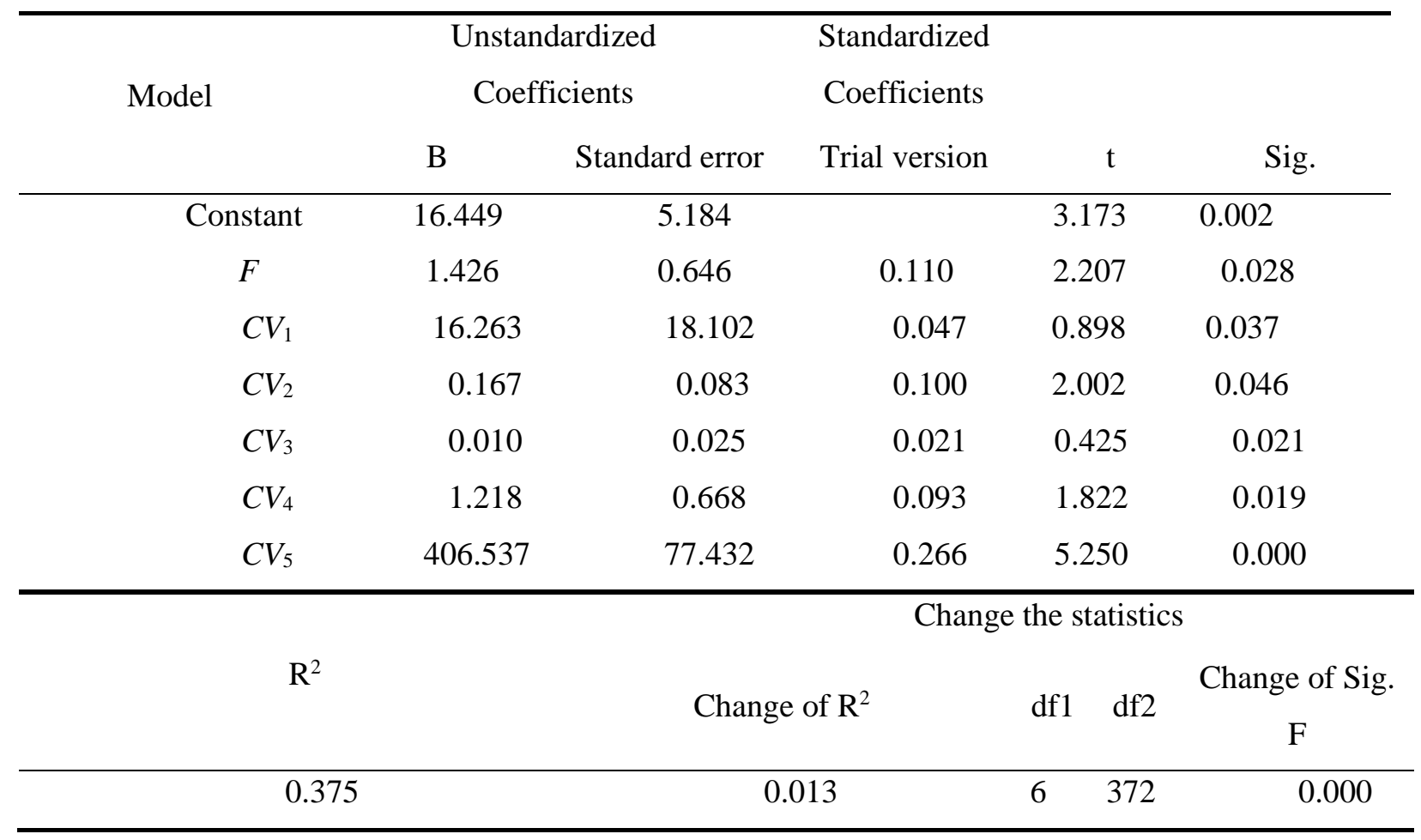


TABLE 5

REGRESSION ANALYSIS BETWEEN OPTIMIZED ENTERPRISE GROWTH INDEX F'AND RETURN ON VENTURE CAPITAL

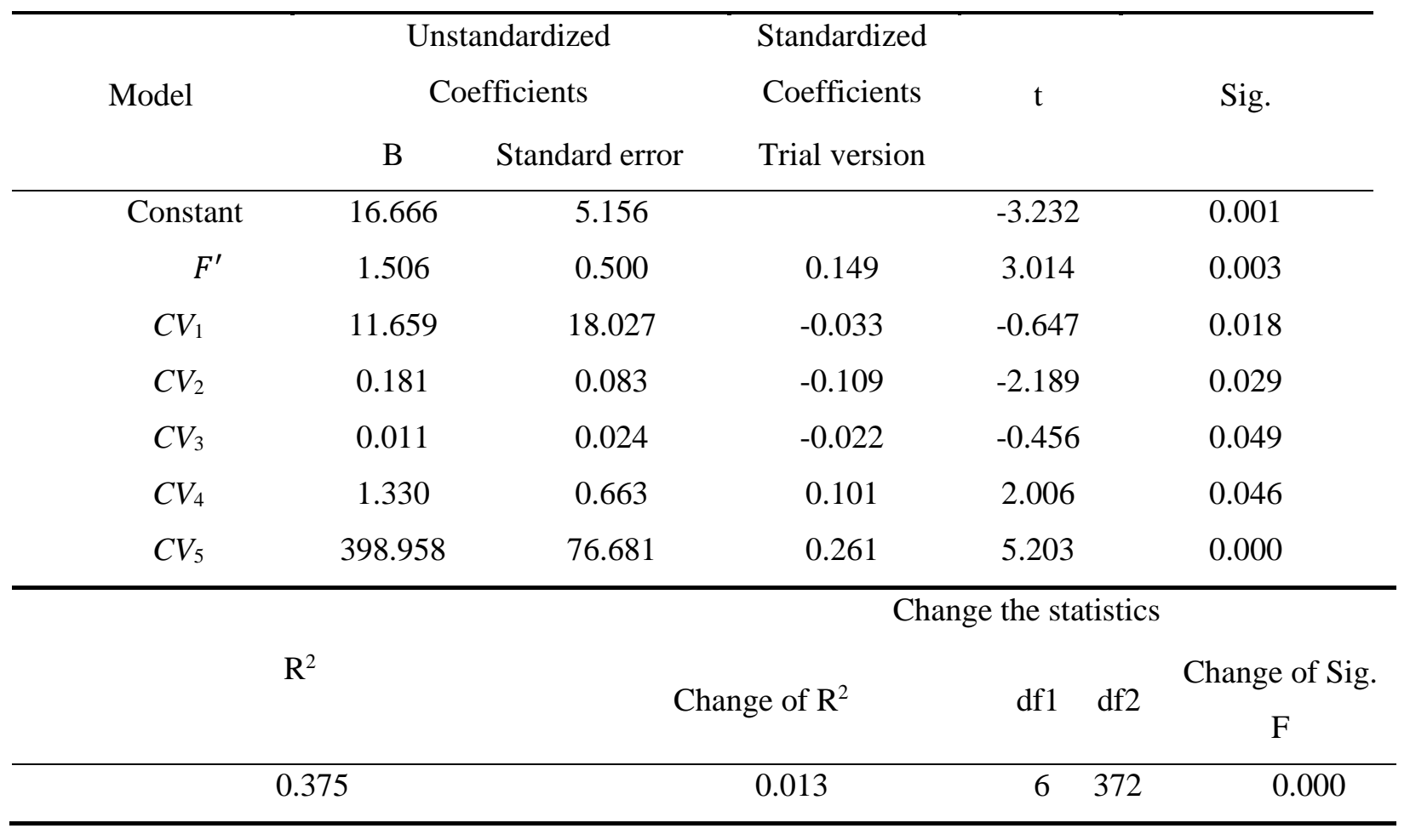

This article also has practical implications for venture capital investors and venture enterprises. First, profitability largely impacts the growth potential. Venture enterprises need to increase profitability so that they can outcompete others in the same industry or in GEM. Second, operational capability is another dimension that VC investors need to look at. Venture enterprises operate with less asset to have the highest productivity in shortest time tend to have highest efficiency and best return for their investors. Finally, enterprise mangers need to upgrade their mode of innovation, research and technology innovation and management innovation to showcase that their enterprises will have the high return for their investors.

This study is not without limitation. First, there is a slight lag of the sample data caused by the data acquisition limit; Second, the return on venture capital only selected samples from the IPO exit, and it cannot completely show all the way out. Finally, this is not a longitudinal study, the causal relationship needs to validate with future studies.

\section{CONCLUSION}

This research examined the antecedents of return on deal-specific venture capital investment. We found that entrepreneurial enterprise profitability, operation ability, and innovation are significantly positively related to the return on venture capital investment. The optimized growth index is significantly positively related to return on venture capital investment. This indicates that when venture capitalists make investment decisions, one of the major evaluation criteria can be the potential growth of the enterprise. Particularly, they shall consider simultaneously enterprise profitability, operational ability and innovation. 


\section{REFERENCES}

Amit, R., Brander, J., \& Zott, C. (1998). Why do venture capital firms exist? Theory and Canadian evidence. Journal of Business Venturing, 13, 441-466.

Barry, C.B. (1994). New directions in research on venture capital finance. Financial Management, 23, 315.

Benson, D., \& Ziedonis, R.H. (2010). Corporate venture capital and the returns to acquiring portfolio companies. Journal of Financial Economics, 98, 478-499.

Boocock, G., \& Woods, M. (1997). The Evaluation Criteria Used by Venture Capitalists: Evidence from A UK Venture Fund. International Small Business Journal, 16(4), 56-59.

Bottazzi, L., \& Da Rin, M. (2002). Venture Capital in Europe and the Financing of European Innovative Firms. Economic Policy, 17(1), 229-69.

Bygrave, J., \& Timmons, M. (1992). Venture Capital at Crossroads (pp. 121-125). Boston: Harvard Business School Press.

Cao, Q. (2008). The Private Equity Research of Small and Medium-Sized Enterprises in China (pp. 3436). Shanghai: Fudan University.

Capon, N., Farley, J.U., \& Hoenig, S. (1990). Determinants of financial performance: A meta-analysis. Management Science, 36(10), 1143-1159.

Cassiman, B., \& Veugelers, R. (2002). R\&D Cooperation and Spillovers: Some Empirical Evidence from Belgium. American Economic Review, 92(4), 1169-1184.

Chahine, S., \& Filatotchev, I. (2008). The Effects of Venture Capitalist Affiliation to Underwriters on Short-and Long-term Performance in French IPOs. Global Finance Journal, 18(3), 351-358.

Coad, A. (2006). A Closer Look at Serial Growth Rate Correlation. [Working Paper]. LEM.

Cohen, W., \& Levinthal, D. (1989). Innovation and Learning: The Two Faces of R\&D. Economic Journal, 99(397), 569-96.

Cohen, W., \& Levinthal, D. (1990) Absorptive Capacity: A New Perspective on Learning and Innovation. Administrative Science Quarterly, 35(1), 128-52.

Croce, A., Martí, J., \& Murtinu, S. (2013). The Impact of Venture Capital on the Productivity Growth of European Entrepreneurial Firms. Journal of Business Venturing, 28(4), 489-510.

Cumming, G., \& Macintosh, J. (2002). Venture Capital Exits the Canada and the United States. Toronto: University of Toronto. Research Paper, pp. 46-48.

Da Rin, M., \& Penas, M.F. (2015). Venture capital and innovation strategies [working paper].

Das, S., Jagannathan, M., \& Sarin, A. (2003). Private Equity Returns: An Empirical Examination of the Exit of Venture-backed Companies. Journal of Investment Management, 8(1), 211-216.

Davidsson, P., Steffens, P., \& Fitzsimmons, J.R. (2009). Growing profitable or growing from profits: Putting the horse in front of the cart? Journal of Business Venturing, 24(4).

DeClercq, D., \& Dimov, D. (2003). A Knowledge-based View of Venture Capital Firms, Portfolio Investment Specialization and Syndication. Frontiers of Entrepreneurship Research, 4(21), 254 257.

Delmar, F., \& Davidsson, P. (2003). William B. Arriving at the High-growth Firm. Journal of Business Venturing, 5(3), 189-205.

Department of the Ministry of Finance Audit Evaluation. (1999). For an Explanation of State-owned Capital Negative Rating System. Finance and Accounting, 31(8), 11-14.

Erik, K., \& Lehmann, J. (2006). Dose Venture Capital Syndication Spur Employment Growth:

Shareholder Value Evidence from German IPO Data. Small Business Economics, 26(5), 455-461.

Fitza, M., \& Sharon, F. (2009). Do VCs Matter: The Importance of Owners on Performance Variance in Start- up Firms. Strategic Management Journal, 30(4), 377-390.

Gerasymenko, V., De Clercq, D., \& Sapienza, H.J. (2015). Changing the Business Model: Effects of Venture Capital Firms and Outside CEOs on Portfolio Company Performance. Strategic Entrepreneurship Journal, 9(1), 79-98. 
Gittins, T., Lang, R., \& Sass, M. (2015). The Effect of Return Migration Driven Social Capital on SME Internationalisation: A Comparative Case Study of IT Sector Entrepreneurs in Central and Eastern Europe. Review of Managerial Science, 9(2), 385-409.

Gompers, P.A. (1995). Optimal investment, monitoring, and the staging of venture capital. Journal of Finance, 50, 1461-1489.

Grilli, L., \& Murtinu, S. (2014). Government, Venture Capital and the Growth of European High-tech Entrepreneurial Firms. Research Policy, 43(9), 1523-1543.

Hayes, R.D., \& Upton. (1998). Operations-based strategy. California Management Review, 40(4), 451466.

Hop, C., \& Rieder, F. (2006). What drives Venture Capital Syndication.

Huang, W., Boateng, A., \& Newman, A. (2016). Capital structure of Chinese listed SMEs: An agency theory perspective. Small Business Economics, pp. 1-16.

Kaplan, S., \& Schoar, A. (2005). Private Equity Performance: Return Persistence and Capital Flows. [Working Paper]. MIT Sloan, 60(4), 791-801.

Kaplan, S.N., \& Stromberg, P. (2000). How do venture capitalists choose investments? [Working Paper] 121, 55-93. University of Chicago.

Li, S., Shang, J., \& Slaugher S.A. (2010). Why do software firms fail? Capabilities, competitive actions, and firm survival in the software industry from 1995-2007. Information System Research, pp. 631-654.

Ljungqvist, A., \& Richardson, M. (2003). The cash flow, return and risk characteristics of private Equity. Finance Working Paper, 9(8), 1-3. NYU.

Manigart, S. (2002). Determinants of required return in venture capital investments: A Five-country study. Journal of Business Venturing, 6(17), 291-295.

Mason, A., \& Harrison, T. (2002). Is It Worth It: The Rates of Return from Informal Venture Capital Investments. Journal of Business Venturing, 24(17), 68-70.

Mason, C., \& Pierrakis, Y. (2013). Venture Capital, the Regions and Public Policy: The United Kingdom since the Post-2000 Technology Crash. Regional Studies, 47(7), 1156-1171.

Nahata, R. (2008). Venture Capital Reputation and Investment Performance. Journal of Financial Economics, 90(2), 23-34.

Neto, J.V., Filho, J.R., \& Quelhas, O.L. (2014). Raising Financial Resources for Small and Medium Enterprises: A Multiple Case Study with Brazilian Venture Capital Funds in the Cities of Rio De Janeiro and São Paulo. International Journal of Innovation and Sustainable Development, 8(1), 77-91.

Ollor, W.G., \& Dagogo, D.W. (2009). The Effect of Venture Capital Financing on the Economic ValueAdded Profile of Nigerian SMEs. African Journal of Accounting, Economics, Finance and Banking Research, 5(5).

Peneder, M. (2010). The Impact of Venture Capital on Innovation Behaviour and Firm Growth. Venture Capital, 12(2), 83-107.

Phalippou, L., \& Gottschalg, A. (2006). The Performance of Private Equity Funds. [Working Paper]. 14(7), 47-52. University of Amsterdam and HEC Paris.

Rosenbusch, N., Brinckmann, J., \& Muller, V. (2012). Does acquiring venture capital pay off for the funded firms? A meta-analysis on the relationship between venture capital investment and funded firm financial performance. Journal of Business Venturing, 28(3), 335-353.

Roth, A.W., \& Jackson, III. (1995). Strategic determinants of service quality and performance: Evidence from the banking industry. Management Science, 41(11), 1720-1733.

Sahlman, W.A. (1990). The structure and governance of venture-capital organizations. Journal of Financial Economics, 27, 473-521.

Smolarski, J., \& Kut, C. (2011). The Impact of Venture Capital Financing Method on SME Performance and Internationalization. International Entrepreneurship and Management Journal, 7(1), 39-55.

Vissing-Jorgensen, A., \& Moskowitz, T. (2000). The Private Equity Premium Puzzle. CRSP Working Paper, 3(5), 261-264. 
Wang, Y.L. (2013). Growth of the Listed Medium-Sized and Small Enterprises in China. Social Sciences Journal of Universities in Shanxi, 25(9), 49-52.

Wright, M., \& Robbie, K. (1998). Ahbrington M. Venture Capital in Europe [3(5), 5-8]. London.

Yu, J.H. (2011). Research on the Investment Decision and Performance of China Private Equity Fund (pp. 56-59). Shanghai: East China Normal University.

Zahra, S., \& Gerard, G. (2002) Absorptive Capacity: A review, Reconceptualization, and Extension. Academy of Management Review, 27(2), 185-203.

Zhang, B., \& Pei, H.Y. (2008). The Important Factors that Affect Risk Investment IPO Exit Manner, and the Empirical Analysis. Modernization of Management, 21(1), 56-58.

Zhang, Q.N. (2013). Analysis of Factors Affecting the Growth of Gem Enterprise. Hainan Finance, 7(11), 26-31.

Zuo, H.Q. (2013). Discussion about the Evaluation Index of Start-ups Company Growth - Based on the Perspective of Risk Investment. Financial Supervision, 4(1), 58-63. 